\title{
CONTORNOS DO ESPAÇO AUTOBIOGRÁFICO: O AUTORRETRATO LITERÁRIO EM SERGIO KOKIS
}

\author{
Luciano Passos Moraes \\ Colégio Pedro 11
}

\section{RESUMO}

Entre as diversas (e controversas) modalidades das escritas de si, o autorretrato literário permanece um terreno pouco explorado teoricamente. Embora o termo emprestado às artes visuais já integre a escrita literária há muito tempo, sua conceitualização continua escorregadia, sobretudo na literatura contemporânea, em que se observa uma hibridação de diversos subgêneros do autobiográfico. No intuito de contribuir à reflexão acerca da projeção de si nessa categoria da autoescrita, propõe-se no presente trabalho, inicialmente, uma atualização de ideias de Michel Beaujour, crítico que se debruçou sobre o tema nos anos 1980, em diálogo com as recentes análises de Robert Dion e Frances Fortier. Tal empreitada oferece base teórica para uma análise de textos autobiográficos do pintor e escritor de origem brasileira radicado no Quebec Sergio Kokis, em especial, da obra L'amour du lointain (2012), autorretrato literário que tem como mote o mergulho nos bastidores de sua criação ficcional. Extrapolando o exercício da autoanálise, Kokis propõe nesse texto uma revisão das bases de sua escrita romanesca, ao retraçar certos caminhos do vivido para contribuir igualmente à crítica literária e à impressão de sua experiência como leitor e pintor, sem deixar de revelar as inconsistências e contrariedades dos rótulos da escrita autobiográfica.

PALAVRAS-CHAVE: Autorretrato. Espaço autobiográfico. Escritas de si. Literaturas migrantes. Sergio Kokis. 

protéger de l'invasion du vulgaire sont aussi de nouvelles sources précieuses pour avoir accès à ce moi-même silencieux du temps où il n'était que peintre et rêveur.

As noções de "fabulação" e "mentira" são recorrentes na obra de Sergio Kokis, pintor e escritor de origem brasileira estabelecido no Canadá em 1979 e considerado um dos expoentes das ditas escritas migrantes, expressão que abarca, no sistema literário do Quebec, escritores oriundos de diversas partes do globo. Kokis aborda em sua produção romanesca as histórias de vida de sujeitos imigrantes, exilados, errantes, que apresentam em seus percursos identitários os traumas da experiência migrante. Híbridas por excelência, suas personagens enfrentam a problemática do não pertencimento e a busca por autoconhecimento ao explorarem terrenos intermediários onde os limites territoriais não são suficientes para defini-los.

Não por coincidência, o próprio Sergio Kokis também carrega, em sua história pessoal, a experiência da migrância, escrevendo em uma língua estrangeira - o francês - e empreendendo uma análise das implicações do percurso migrante em sua constituição identitária. Se na produção romanesca de Kokis a temática do trânsito é uma constante, a hibridação entre as instâncias ficcional e referencial também pode ser observada, uma vez que ele se alimenta de sua história pessoal para criar via ficção personagens que vivem o deslocamento e as questões identitárias dele decorrentes.

À parte sua produção ficcional, o escritor também se posiciona criticamente para verificar inconsistências e apontar contrariedades quanto à recepção de sua obra, em publicações que se afastam do romanesco para se aproximarem do espaço autobiográfico. É nelas que são empregadas com certa insistência as noções de "mentir" e "fabular", constituindo um 
jogo em que elas são postas lado a lado com uma escrita pessoal, mas em cujo interior são recusados os rótulos de autobiografia e de autoficção.

Nessa empreitada, destacam-se publicações como entrevistas e artigos, mas, no conjunto da produção referencial de Sergio Kokis, um texto chama especial atenção quando da análise das relações entre os subgêneros do autobiográfico. Trata-se de L'amour du lointain (2012), uma das raras obras que não estabelece explicitamente o pacto romanesco por meio do recurso ao epíteto "romance" e que se diferencia, inicialmente, por ser chamada, pelo próprio autor, de autorretrato. Interessa observar os meandros desse subgênero do espaço autobiográfico porque a obra revela a migração genérica que ultrapassa as fronteiras entre pacto romanesco e autobiográfico, resultando em uma escrita compósita exemplar no universo literário de Kokis.

Dentre as diferentes expressões empregadas para designar possíveis contornos do espaço autobiográfico, faz-se necessário analisar em detalhe o tema do autorretrato, que aproxima o universo da escrita autobiográfica ao da pintura. As questões postas em jogo na escrita de um retrato podem ser vistas como clara estratégia de recusa, por parte do autorretratado, ao encarceramento teórico realizado pela crítica literária quando tenta definir com clareza as balizas da escrita autobiográfica. O termo autorretrato, tomado emprestado às artes visuais, ressurge nos estudos das escritas de si como um conceito amplo e relativizável, sujeito a diversas nuances que o tornam tão escorregadio quanto instigante.

Ao final dos anos 1970, quando se assistiu à ascensão dos estudos das escritas de si, cujo marco foi a publicação do Pacto autobiográfico de Philippe Lejeune (a primeira e controversa edição foi publicada em 1975, retomada e reformulada anos mais tarde), o autorretrato ainda era pouco explorado criticamente. Michel Beaujour, em 1980, foi um dos primeiros a trazer essa noção à ordem do dia, à luz dos estudos da recepção. No capítulo de abertura de Miroirs d'encre, ele considera que

se há muito tempo se debate o que é a autobiografia, como o prova a abundância de trabalhos teóricos e críticos que tratam desse gênero, o autorretrato não foi objeto de nenhuma reflexão teórica [...]. Os autorretratistas praticam o autorretrato sem o saber. Esse "gênero" não oferece nenhum "horizonte de expectativa". Cada autorretrato é escrito como se fosse único em seu gênero (BEAUJOUR, 1980, p. 8). ${ }^{1}$ 
Evidentemente, passados mais de trinta e cinco anos desde a publicação do texto de Beaujour, os estudos acerca do tema avançaram enormemente, o que não significa que haja um consenso quanto ao que o autorretrato representa na atualidade. Permanece a ideia de que cada autorretrato é único - prova disso é a forma como escritores e editores empregam o termo, situando a noção de autorretrato em um espaço intermediário no qual se desenvolvem características do relato autobiográfico e da escrita ficcional. A falta de "horizonte de expectativa" a que se refere Beaujour parece ser, ainda hoje, uma lacuna conveniente para que se considere o autorretrato literário um gênero híbrido, plural e rico em sentidos. Para ele, o autorretrato corresponde a "um discurso fora, que os historiadores e os teóricos tendem ainda a designar de modo restritivo ou negativo: o que não é de fato uma autobiografia" (BEAUJOUR, 1980, p. 8 , grifos nossos).

Beaujour apresenta pistas do que o diferencia de outras modalidades: "O autorretrato se distingue da autobiografia pela ausência de um relato contínuo. E pela subordinação da narração a um desdobramento lógico, reunião ou bricolagem de elementos em categorias que chamaremos provisoriamente de "temáticas"” (BEAUJOUR, 1980, p. 8). Um dos traços distintivos entre autorretrato e autobiografia seria o emprego de diferentes estratégias de narração: o autorretrato é uma categoria cuja narratividade passa pelo uso metafórico e poético da linguagem. Nele, a coerência se constrói por meio do acesso a instantes de memória, retomadas e superposições não lineares, conferindo ao texto uma aparência de descontinuidade.

Para analisar os mecanismos usados nas escritas migrantes e autobiográficas de Sergio Kokis, o tema do autorretrato solicita especial atenção, sobretudo quando da leitura de alguns de seus textos considerados não ficcionais (tanto pelo autor quanto por seus editores). Não há consenso quanto ao emprego do termo, assim como não são claros os limites que determinam se um texto pertence mais ao campo autobiográfico ou ao ficcional. Essa falta de clareza é reveladora de pelo menos dois aspectos: por um lado, pode ser entendida como evidência do quão problemático é ainda, nos dias de hoje, circunscrever e delimitar as categorias genéricas ligadas às escritas de si. Por outro lado, ao embaralhar as instâncias propostas pela crítica, Kokis desafia os limites de gênero impostos pelas teorias, jogando deliberadamente com dados biográficos e ficcionais, utilizando outros meios que não o texto literário (entrevistas a 
jornais e revistas, por exemplo) para contradizer a crítica, demonstrando assim sua fragilidade.

Em L'amour du lointain, Kokis oferece acesso ao que haveria por detrás de sua escrita dita ficcional. Publicado originalmente em 2004, o texto estabelece um jogo de ambiguidades entre a escrita autobiográfica e a ficcional, do qual não parece fazer parte o caráter confessional, por mais inusitada que seja tal ideia: o escritor diz guardar para si, no íntimo, uma série de questões que prefere não revelar. Mesmo assim, ele abre as portas de seus processos de escrita, compartilhando com o leitor os bastidores de sua produção, sobretudo dos três primeiros romances. Em suma, ele propõe uma exposição (ainda que parcial) de acontecimentos de sua vida que teriam servido de matéria para sua escrita ficcional.

É o próprio Kokis que se apresenta como narrador em primeira pessoa - diferente daqueles presentes em seus romances, nos quais geralmente são alternadas passagens narradas pela personagem protagonista com outras conduzidas por um narrador onisciente. A voz que apresenta os relatos em L'amour du lointain propõe-se a caminhar à margem de seus outros textos, traçando um panorama de sua vida e entrecruzando os momentos vividos com a experiência de criação dos romances.

Logo na introdução, o autor afirma tratar-se de um relato muito pessoal, uma proposta diferente da criação de um texto ficcional (KOKIS, 2012, p. 11), o que leva o leitor a pensar estar diante de uma autobiografia. No entanto, ao final do primeiro capítulo, essa suspeita é desafiada pelo autor:

Mas atenção, leitor ocioso ou crítico rancoroso: lembre-se que isso não é uma autobiografia nem uma confissão, mas somente uma tentativa de autorretrato. Sou eu, o artista, e eu falarei unicamente do que ajudará a me compreender. Muitas coisas íntimas, coisas preciosas ou coisas que tenho ainda dificuldade de aceitar continuarão veladas porque elas só dizem respeito a mim. Não se sobrecarregue demais com a verdade e divirta-se antes com a verossimilhança (KOKIS, 2012, p. 38).

A leitura desse trecho faz pensar em Beaujour, quando traz a hipótese do autorretrato como um lugar de negação/restrição - aquilo que não $e ́$ autobiografia. Kokis coloca em xeque algumas das classificações impostas pela crítica: ao negar as categorias "autobiografia" e "confissão", busca um espaço intervalar, situando a noção de autorretrato entre uma verdade do escritor/artista ao produzir a obra e uma verdade íntima, ligada à ficção, do sujeito empírico. É como se, ao tomar emprestado o termo 
da pintura, entrasse num espaço mais sutil, menos estanque, para ocupar um terreno mais fértil em possibilidades de sentido. Vale destacar aqui que, além do ofício da escrita, Kokis também se dedica à pintura - dado importante sobretudo quando se observa sua afirmação "sou eu, o artista". A expressão "ser artista" está intimamente relacionada ao ofício da pintura; o escritor/pintor/autorretratista coloca-se como o principal conhecedor dos meandros da criação, seja ela literária ou pictórica.

Ao longo do relato, Kokis afirma ter adotado máscaras em diversos momentos de sua vida: "desde minha primeira infância, tive de construir múltiplas máscaras mundanas e carapaças para não ser invadido, para proteger esses lugares íntimos onde eu celebro minhas missas e meus mitos os mais caros" (KOKIS, 2012, p. 17). A própria forma de tratar o texto, dizendo que não é uma autobiografia e sim uma espécie de autorretrato, pode ser também uma forma de mascarar seu projeto, para confundir e escapar às formulações teóricas que insiste em recusar. Ao se dirigir aos "críticos rancorosos", Kokis parece se referir tanto à crítica acadêmica quanto aos - na verdade, às - jornalistas que o procuram para entrevistá-lo. Ele parece incomodado com essa abordagem, o que justifica em certa medida a estratégia de criar máscaras e carapaças para se proteger. A relação conturbada com os críticos é objeto de sua análise, como na seguinte passagem:

Eu me pergunto até se os avatares do trabalho autônomo para as páginas literárias dos jornais não têm efeitos tóxicos sobre certas naturezas simples, como certas meninas recém-saídas de vagos estudos do tipo comunicações ou criação literária. Mas que verve! Elas vêm, no entanto, armadas com seu gravador; bastaria transcrever a entrevista para ter um textinho confiável. Mas não, elas partem logo em seguida para interpretações projetivas as mais mirabolantes, guiadas por suas necessidades íntimas não confessadas, sem dúvida como elas se lembram de ter visto fazerem os psiquiatras nas novelas americanas da televisão (KOKIS, 2012, p. 33).

Sua declaração ácida e algo misógina tem a ver com a máscara de ironia de que ele se reveste em outros momentos. Tal estratégia é reveladora de sua tendência a escapar a classificações e a recusar qualquer pretensão dos críticos quanto a conhecer a fundo os bastidores de seu trabalho ou de sua própria vida. Esse é, finalmente, um dos objetivos traçados pelo autor em L'amour du lointain: tomar ele próprio as rédeas da autoanálise valendo-se do recurso à memória. A ferramenta utilizada é o 
discurso, a linguagem, como ele próprio já indicara no ensaio Les langages de la création (1996).

Mesmo que Kokis evite a noção de autobiografia no relato, alguns elementos deixam claro tratar-se de um texto construído no espaço autobiográfico, com uma escrita bastante distinta da de seus romances. O narrador assume o nome Sergio Kokis, fala na primeira pessoa do singular e diz que o texto é resultado de um balanço a que se propõe ao completar sessenta anos. Entre os críticos, há quem considere L'amour du lointain uma "narrativa autobiográfica", um "texto-comentário", uma "chave de interpretação de seus textos e de seus quadros" (ERTLER, 2007, p. 76), mas também há quem o chame de "romance" ou "romance autobiográfico" (KOHLER, 2011, p. 59). Seja como for, é importante compreender de que modo ele adentra o espaço autobiográfico no texto em questão. Uma vez que seu interesse principal está centrado no "eu", fica evidente tratar-se de um gesto autobiográfico, o que evidencia o caráter híbrido dos escritos, em posição intervalar entre ficção e autobiografia.

Michel Beaujour considera que

o autorretrato é inicialmente um objeto encontrado ao qual o escritor confere uma finalidade de autorretrato em curso de elaboração. Espécie de mal-entendido, ou de compromisso, vai e vem entre a generalidade e a particularidade: o autorretratista nunca sabe claramente aonde vai, o que faz. Mas a sua tradição cultural o sabe por ele: e é ela quem the fornece prontas as categorias que lhe permitem ventilar as migalhas de seu discurso, de lembranças e de fantasmas (BEAUJOUR, 1980, p. 10).

Quanto ao "objeto encontrado", pode-se dizer, no caso de Kokis, tratar-se de um autorretrato pautado na criação de sua obra ficcional, análise posterior à publicação e à recepção de seus primeiros romances. Quanto às “migalhas", ele próprio se encarrega de tentar organizá-las em unidades temáticas, embora a narrativa apresente a descontinuidade ou falta de linearidade de que fala Beaujour. O fato de Ertler e Kohler classificarem o relato de Kokis de maneiras tão distintas é revelador da tensão genérica estabelecida quando essas migalhas são reunidas. Trata-se da dificuldade de se circunscrever sob a égide de um mesmo conceito como o autorretrato a amplitude do exercício da escrita de si. Essa seria uma de suas características fundamentais, a impossibilidade de se estabelecer uma clara conceitualização:

Parece, aliás, que as tentativas de teorização imanentes aos autorre- 
tratos - e que constituem, em diferentes graus, um de seus traços distintivos - são insuficientes, fragmentárias e míopes, na medida em que todas elas desconhecem em diferentes graus a matriz retórica cuja consciência mais clara paralisaria, levando talvez a certa inanidade, a escrita de um autorretrato (BEAUJOUR, 1980, p. 12).

Especialista do autorretrato em suas diversas representações midiáticas, Hans-Jürgen Lüsebrink propõe a seguinte tentativa de definição:

O autorretrato, para além de suas múltiplas variações, caracteriza-se pela intenção de fixação na imagem do autor - escritor, artista ou intelectual - e mais frequentemente em seu rosto, que deve representar o conjunto de seu corpo e de sua personalidade. Ligado, de maneira explícita ou implícita, à palavra escrita ou impressa, ele forma o ponto de partida e ao mesmo tempo o centro discursivo de uma narração autobiográfica da qual ele condensa de alguma maneira os périplos e o sentido profundo. Entre narrativa autobiográfica, fragmentária ou linear, falada ou escrita (retomada por outros gêneros na dialogicidade da correspondência ou da entrevista), de um lado, e o autorretrato pictórico e visual, de outro, tecem-se assim múltiplos laços suscetíveis de circunscrever uma personalidade e seu vivido ao mesmo tempo no instantâneo e na extensão temporal. O autorretrato visual, oral ou escritural é, então, essencialmente metonímico, remetendo sempre a uma profundidade psíquica ou narrativa ausente, mas indicada ou suspeitada (LÜSEBRINK, 2007, p. 471).

É importante destacar o caráter narrativo do autorretrato: trata-se de uma construção discursiva intervalar que absorve, ao mesmo tempo, a dimensão linear esperada da autobiografia e a fragmentação característica dos escritos ditos pós-modernos (e que alguns críticos atribuem à autoficção). No entanto, ultrapassa linearidade e fragmentação, trazendo como singularidade a subjetividade do discurso, construído também nas bases do não dito ou do sugerido. No caso de Kokis, uma das estratégias empregadas é a autorreferencialidade a partir da negação, quando diz em diversos momentos que seu texto não é autobiografia, nem confissão, nem autoficção.

Robert Dion e Frances Fortier, estudiosos da biografia, consideram que o retrato literário de escritores - e, por extensão, o autorretrato - constitui uma modalidade de escrita (auto)biográfica que extrapola a fixação da imagem. Nessa modalidade, são colocados em movimento instantes da vida do (auto)retratado por meio do acesso a um universo de subjetividades do qual o elemento ficcional faz parte tanto quanto a in- 
tenção do real (DION; FORTIER, 2009, p. 11). Eles também pensam esse gênero em relação à (auto)biografia:

Na biografia, é muito mais o movimento, a transformação, a fluidez de uma personalidade que a narração se encarrega de traduzir. $\mathrm{O}$ retrato representa somente uma estase da biografia, mais ou menos fugaz, no seio do movimento temporal que aciona, frequentemente muito rápido, a narrativa de vida. Em sua versão contemporânea, o retrato, modalidade de conhecimento entre outras, abandona a intenção da semelhança estrita em benefício de uma recriação estética do modelo, parecido com uma escrita biográfica que levou em consideração os limites do substrato documental e reconhece a partir de então as virtudes do imaginário na elaboração de uma verdade biográfica (DION; FORTIER, 2009, p. 14-15).

Seja no retrato ou no autorretrato, o componente imaginário se faz presente na construção da narrativa, já que o relato ultrapassa os limites do documental, como na analogia entre fotografia e história proposta por Roland Barthes ao cunhar o termo biografema. Lançado no prefácio de Sade, Fourier, Loyola (1990), o neologismo fazia referência à captura temporária de um momento, como ocorre na fotografia - outra modalidade, aliás, da expressão do autorretrato pictórico. Barthes declara que, "se fosse escritor, e morto", gostaria de ver sua vida reduzida "a alguns pormenores, a alguns gostos, a algumas inflexões, digamos: "biografemas"” (BARTHES, 1990, p. 12).

Biografemas seriam pequenos indícios, fragmentos do ser que ajudam a construir um certo espaço biográfico por meio da referência a aspectos muito particulares do corpo ou do comportamento daquele que escreve. O biografema é fragmentário, incompleto, instantâneo, faz parte de um conjunto textual sem dar a ideia de totalidade.

O neologismo seria retomado e reelaborado posteriormente em outros de seus textos, como no ensaio A câmara clara, cujo objeto de análise é a fotografia: "gosto de certos traços biográficos que, na vida de um escritor, me encantam tanto quanto certas fotografias; chamei esses traços de 'biografemas'; a Fotografia tem com a História a mesma relação que o biografema com a biografia” (BARTHES, 2012, p. 34). A comparação parece clara, mas no fundo aponta para o caráter fragmentário e inconcluso da escrita: a fotografia é para a história todo um universo de possibilidades, pois pode servir como documento, evidência, ilustração, sem deixar de ser uma entidade independente com suas próprias especificidades 
que vêm a complementar sentidos sem se transformar em outra coisa. Ela permanece fotografia, instantânea, apenas contribui para a ampliação das possibilidades de significação, sugerindo mais do que afirmando.

Em Roland Barthes por Roland Barthes, ele põe em prática sua quase-obsessão pela imagem, pelo corpo e pelo texto: em diversos trechos, tece seus biografemas através da linguagem, deixando entrever alguns pontos marcantes de sua vida. No fragmento "Pausa: anamneses", ele diz o seguinte:

Chamo de anamnese a ação - mistura de gozo e de esforço - que leva o sujeito a reencontrar, sem o ampliar nem o fazer vibrar, uma tenuidade de lembrança: é o próprio haicai. O biografema [...] nada mais é do que uma anamnese factícia: aquela que eu atribuo ao autor que amo.

Essas poucas anamneses são mais ou menos foscas (insignificantes; isentas de sentido). Quanto mais se consegue torná-las foscas, mais elas escapam ao imaginário (BARTHES, 2003, p. 126).

Trata-se de instantes reveladores do eu constituídos por fragmentos de memória que alimentam as narrativas no espaço autobiográfico. Madeleine Ouellette-Michalska parece dialogar com esse fragmento ao trazer ao debate a ideia de que "a teoria freudiana da lembrança-tela, segundo a qual a memória registra o que é 'indiferente' mais do que o que é 'significativo', hipoteca a verdade autobiográfica, uma vez que ela fornece às literaturas pessoais estatuto de ficção inevitável” (OUELLETTE-MICHALSKA, 2007, p. 39).

A impossibilidade de uma totalidade da lembrança é evocada pela imagem da tela, em pausa, tal como uma cena onírica, ou uma cena congelada em um filme, ou mesmo uma fotografia ou autorretrato, representando objetos ou situações ausentes ou censurados, que só se revelam em pequenos instantes simbólicos. Tal imagem, ligada à ideia de biografema, faz pensar no caráter seletivo dos relatos que compõem as narrativas pessoais, impulso do eu que exerce algum controle sobre essa seleção.

Esse aspecto é característico das escritas de si na contemporaneidade, já que o compromisso com o real cedeu lugar à reescrita ficcional do real - um dos pontos abordados nas teorias da autoficção, por exemplo. Resta como hipótese de diferenciação do autorretrato literário o uso do temporal: a organização não linear e temática da narrativa remete ao caráter instantâneo do vivido, como pequenos flashes postos em movimento pela via do discurso. Aliada ao uso criativo do documental, desponta aí a 
elaboração de uma verdade, possibilidade entre muitas de se contrapor o vivido e o imaginado.

Quanto à alternativa proposta por Kokis de classificar L'amour $d u$ lointain como um autorretrato, cabe destacar que, não por acaso, a imagem que ilustra a capa é um de seus autorretratos em óleo sobre tela, pintura intitulada Autoportrait en Saint Antoine, de 1993. Ao pensar as relações entre autobiografia e pintura, Eurídice Figueiredo relembra:

A escrita autobiográfica tem seu correspondente na pintura através do autorretrato. Todos os grandes pintores o praticaram, assim como muitos se colocaram na tela enquanto pintavam, como no célebre quadro As meninas, de Velasquez. O pintor contemporâneo Lucian Freud, que faz retratos e autorretratos, também distingue o eu do pintor de sua imagem no autorretrato, dizendo que é preciso pintar a si mesmo como um outro (FIGUEIREDO, 2013, p. 25).

O termo autorretrato nas artes visuais tem como correlatas as noções de autorreflexão e autorrepresentação, tocando, portanto, o espaço autobiográfico. Com o foco sobre o rosto do artista, as imagens tendem a expor uma visão pessoal e particular (ou mesmo parcial) de si, geralmente mostrando seu lado sombrio e angustiado, como no quadro reproduzido na capa de L'amour du lointain. O autorretratado está posicionado ao centro, com uma expressão vaga, reflexiva, acotovelado sobre uma mesa e com um cigarro entre os dedos da mão direita, que segura a cabeça, acentuando seu olhar contemplativo. Sobre a mesa há uma garrafa, e o autorretratado encontra-se rodeado de figuras macabras que tentam tocá-lo. Como é comum entre os quadros de Kokis, essas personagens do entorno parecem gritar, sofrer, e algumas remetem à morte, como esqueletos e outras figuras cadavéricas. Apesar do ambiente de angústia, o semblante da figura central parece sereno, ou alheio ao que está a sua volta, dando uma ideia de melancolia e constituindo no conjunto do quadro um híbrido entre tranquilidade e horror. A ilustração da capa vai, portanto, de par com o conteúdo do livro: o narrador debruça-se sobre si, sua vida passada e seu processo criativo.

As figuras macabras que acompanham a personagem do autorretrato fazem pensar, também, nos espectros abordados no primeiro romance de Kokis, A casa dos espelhos (Le pavillon des miroirs, lançado originalmente em 1994, traduzido e publicado no Brasil em 2000). O título vem do fato de o pintor-escritor que protagoniza a obra encontrar-se cercado de quadros sombrios cujas personagens seriam uma projeção deformada 
de si, como nas salas de espelhos alterados em parques de diversão. São imagens grotescas que podem representar ao mesmo tempo o passado obscuro anterior ao exílio e os fantasmas que perseguem o escritor no novo estatuto identitário de imigrante: sentir-se outro, ser o outro com relação ao grupo de referência encontrado na nova sociedade em que se estabelece. Assim, o narrador Kokis de L'amour du lointain aproxima-se da personagem do primeiro romance ao tentar mirar-se em um espelho deformado, buscando uma projeção de si que nunca é completa. O acesso à memória é sempre parcial, e sendo o passado matéria de sua autoescrita migrante, a recomposição do sujeito na narrativa ultrapassa os limites do ficcional e do real.

A postura da personagem na capa de L'amour du lointain lembra outro quadro de Sergio Kokis, Dans le bar, que ilustra a capa de Errances (1996), seu terceiro romance. Na imagem, quatro homens estão posicionados em torno de uma mesa de bar, num ambiente que remete à atmosfera evocada pelo título, com garrafas, copos e um foco de luz direcionado para a mesa. Dois homens, ao centro, aparecem com a cabeça apoiada na mão direita, o primeiro deles também segura um cigarro entre os dedos. As quatro personagens parecem ter o olhar distante, algo melancólico, numa mistura de ebriedade e tédio, o que faz pensar nas conversas de bar que são retomadas em diversas passagens de romances de Kokis, quando o álcool e o fumo são coadjuvantes nos diálogos e divagações de personagens boêmias e errantes.

Ao tentar definir uma subcategoria que chamou de autoficção fantástica, Vincent Colonna recorreu ao universo da pintura para estabelecer uma comparação entre os recursos em jogo na representação pictórica de si e aqueles de que lança mão o escritor da autoficção. Embora esse não seja o caso das obras aqui analisadas, pois elas se distanciam bastante do conceito de autoficção fantástica, é pertinente recuperar sua reflexão uma vez que os quadros que utiliza para embasar sua comparação lembram em alguns aspectos as imagens de Kokis aqui evocadas:

Em direção bem diferente, como Van Gogh, e também Rembrandt, que nisso foi insuperável, Frida Kahlo e Lucian Freud, que levaram sua nudez mortificada ao mais alto grau, pintores praticaram uma forma ascética de autorretrato, mais empenhados em desvelar de maneira clínica as corrupções de seus próprios rostos e corpos do que preocupados com a busca de semelhança. Há, no entanto, uma distância entre essas licenças pictóricas (vejam a liberdade gráfica do Autorretrato 
com caveira, 1972, de Picasso) e uma representação de si situada em um mundo mítico ou lendário. A autoficção fantástica difere assim da fabulação biográfica, da mesma maneira que a representação in figu$r a$ se distingue do autorretrato, tradicional ou ascético (COLONNA, 2014, p. 41).

Parece, assim, que aquilo que Kokis chama de autorretrato na pintura não corresponde aos parâmetros do que empreende como autorretrato literário. No universo presente no quadro, ele se aproxima um pouco do caráter ascético por meio do recurso a tons escuros, imagens macabras e sombrias e da presença da morte como elemento perturbador. No entanto, no que se refere à personagem autorretratada, percebe-se que a relação com o corpo não tem a ver com um desvelamento "de maneira clínica", nos termos de Colonna, pois a personagem principal aparece humanizada, com traços característicos e sob um foco de luz, além da expressão serena já mencionada. Com isso, fica claro que a própria imagem presente na capa do livro é também um híbrido, composto por características do autorretrato ascético, mas cuja personagem autorretratada é representada de forma tradicional.

A ambiguidade das sensações evocadas pelo quadro Autoportrait en Saint Antoine pode ser relacionada ao caráter plural, híbrido e contrastivo da obra literária de Kokis, como sinaliza Joseph Melançon no prefácio do ensaio Les langages de la création:

O universo romanesco de Sergio Kokis, como bem observou a crítica, é feito de contrastes e de fusões. A doçura e a amargura nele se fundem como nas frutas doces e amargas. [...] Em um autorretrato impressionante no qual o pintor se expressa tanto quanto o escritor e o psicólogo, Sergio Kokis fala de uma coerência que o obseda e que lhe escapa, mas que a escrita recupera como uma necessidade (KOKIS, 1996b, p. 8-10, grifo nosso).

Melançon revela a que ponto as questões autobiográficas são controversas e até contraditórias em Kokis: por um lado, ele chama de "malignos" aqueles que acreditaram ver em A casa dos espelhos fragmentos de biografia, num momento em que o escritor havia publicado apenas seus dois primeiros romances. Por outro lado, ele se refere ao ensaio como um autorretrato do artista, termo adotado mais tarde por Kokis em L'amour du lointain.

No processo de hibridação entre ficção e autobiografia observado no autorretrato, o acesso à memória que serve de matéria para os relatos 
passa pela fabulação, termo empregado insistentemente ao longo do texto. A esse respeito, Héliane Kohler afirma:

Operando segundo vias comparáveis à criação literária, a memória, vale lembrar, exige constantemente um trabalho de releitura da parte do sujeito-pensante, demandando a cada vez uma nova organização e uma nova interpretação de seu passado. Também a "fabulação" de que fala Kokis em suas considerações metatextuais (enquanto escritor que evoca e narra suas lembranças) e metapictóricas tem a ver, de um lado, com uma ficcionalização de suas lembranças e, de outro, com uma deformação voluntária ou não de outras (KOHLER, 2011, p. 62).

Explorar o espaço da memória implica adentrar o da ficção, da fabulação, pela seleção e exclusão de elementos. As lembranças do passado no Brasil evocadas por Kokis são borradas, muitas vezes a própria descrição espacial do Rio de Janeiro nos romances não corresponde claramente à geografia da cidade. Essa é apenas uma das evidências da defasagem entre memória e realidade observada em seus textos. Quanto ao elemento fabulador, Nancy Huston considera que a memória é uma ficção, o que "não significa que ela seja falsa, mas que, mesmo não sendo solicitada, ela passa o tempo todo ordenando, associando, articulando, selecionando, excluindo, esquecendo, ou seja, construindo, fabulando" (HUSTON, 2010, p. 24). Para ela, "não existe o mito de um lado e a realidade de outro. O imaginário não apenas faz parte da realidade humana, ele a caracteriza e a engendra" (HUSTON, 2010, p. 87).

Assim, entender a fabulação como parte integrante da vida pode ser uma pista para sair da dualidade realidade versus invenção. Mesmo ao explorar o espaço autobiográfico, o escritor hibridiza as duas instâncias, levando-as a seus limites e mostrando que há que se mudar de perspectiva. Não se trata de procurar o real, o verdadeiro, e sim de compreender e de admitir que a realidade só toma forma a partir da fabulação, da invenção. Tais componentes integram também a noção de autorretrato, no que diz respeito à criação de máscaras. Para Huston, na escrita literária,

não existe fronteira estanque entre "vida verdadeira" e ficção; uma alimenta a outra e dela se alimenta.

Só conseguimos agir e compreender graças à identificação, ao deslocamento, ao afastamento, à simplificação e à essencialização, à semelhança e à representação... Enfim, graças à máscara (HUSTON, 2010, p. 123). 
L'amour du lointain tem também o valor de revelar os bastidores das criações literárias de Kokis. Dentre as máscaras que o autor assume na escrita, cabe destacar a motivação que o leva a escrever Errances:

Eu também, um exilado como Ulisses, tinha desde então a permissão de voltar ao país após um longo período de banimento. De fato, após o fim da ditadura no Brasil, eu estava numa situação análoga à de Odisseu na ilha de Calipso, eu não tinha mais desculpas para permanecer em exílio. Eu tinha pensado muito nessa questão, e minha decisão era clara, sem ambivalência. Mas ficava a curiosidade de ver o país depois de mais de vinte anos de ausência - o mesmo espaço de tempo que Ulisses -, bem como as pessoas que eu conhecera mais jovem. [...] Eu decidi então fazer também essa viagem de retorno, mas sob o disfarce de um personagem inteiramente inspirado em Homero e em Kazantzakis. Seria um livro de viagens como as que eu não pude viver na realidade. E seria também meu acerto de contas, como intermediário, com meu passado brasileiro (KOKIS, 2012, p. 270-2).

Passagens como esta podem contribuir para a compreensão das relações entre ficção e realidade que permeiam a narrativa de Errances. Ao discorrer sobre as máscaras utilizadas na composição de suas personagens, Kokis permite observar, na coxia, alguns processos que o levam a criar suas intrigas colocando em contato a experiência vivida e a imaginação.

No romance, a personagem Boris torna-se uma espécie de Ulisses reinventado, que se desenha através do reflexo no espelho deformado da escrita: o protagonista traz também, em seu percurso, traços semelhantes à história de vida do sujeito empírico autor, embaralhando ainda mais essas instâncias e as constituições identitárias nelas inscritas.

Quanto a L'amour du lointain, trata-se de uma obra híbrida, na qual ficção, memória, autobiografia e ensaio se entrelaçam e oferecem amplo campo de reflexão sobre suas fronteiras, tão frágeis e permeáveis. Para além de classificações conceituais, a obra exemplifica o quanto essa problematização se faz presente ao longo da produção do autor. Fica evidente que a tensão entre os domínios público e privado não chega a ser explorada, já que o "eu" que se constrói é um mosaico de referências a certas experiências supostamente vividas pelo sujeito que escreve e a outras que compõem seus romances. Mais do que isso, para complexificar ainda mais a questão, Kokis parece remeter à necessária diferença entre as figuras do sujeito autor e do sujeito empírico, já que atribui ao primeiro, que é o próprio narrador, as experiências que integram os relatos. 
Não sendo confessional, o autorretrato escrito de Kokis compartilha da tendência contemporânea de desvelar sem necessariamente revelar. Exercício da autoanálise, o autorretrato literário continua a instigar, constituindo ainda uma outra camada das escritas de si. Intermediário, provisório e talvez ainda mais compósito do que os outros subgêneros, o conceito de autorretrato aponta para o íntimo e se traveste de realidade, sem deixar de lado as pinceladas de ficção que tanto contribuem para o enriquecimento estético dessas narrativas.

\section{CONTOURS OF THE AUTOBIOGRAPHICAL SPACE: THE LITERARY SELF-PORTRAIT IN SERGIO KOKIS}

\section{ABSTRACT}

Amongst the various (and controversial) modalities of selfwriting, the literary self-portrait remains a field of little theoretical exploration. Though the term loaned from the visual arts field makes part of the literary creation since long, its conceptual approach still constitutes a slippery soil, especially in contemporary literature, where the hybridization of several subgenres of the autobiography may be observed. Attempting to contribute to the reflection on the self-projection in this particular category of self-writing, the present work aims at actualizing ideas by Michel Beaujour, who has carefully examined the theme in the 1980s, through a dialogue with recent analysis by Robert Dion and Frances Fortier. In this process, we create a theoretical basis to study autobiographical texts by Sergio Kokis, a painter and writer of Brazilian origin established in Quebec, particularly in his work L'amour du lointain (2012), a literary self-portrait that offers access to the backstage of Kokis's fictional creation. Extrapolating the self-analysis exercise, Kokis proposes in this text a review of his Romanesque writing, by recovering certain tracks of his personal history in order to contribute critically and to establish his experience as a reader and a painter, yet revealing the inconsistencies and contrarieties of the labels imposed within the autobiographical writing field.

KEYWORDS: Self-portrait. Autobiographical space. Self-writing. Migrant literatures. Sergio Kokis. 


\section{NOTA}

${ }^{1}$ As traduções de citações de obras em língua estrangeira são de minha responsabilidade, salvo quando houver indicação em contrário nas referências.

\section{REFERÊNCIAS}

BARTHES, Roland. A câmara clara: nota sobre a fotografia. Tradução de Júlio Castañon Guimarães. Rio de Janeiro: Nova Fronteira, 2012.

Roland Barthes por Roland Barthes. Tradução de Leyla Perrone-Moisés. São Paulo: Estação Liberdade, 2003.

. Sade, Fourier, Loyola. Tradução de Mário Laranjeira. São Paulo: Brasiliense, 1990.

BEAUJOUR, Michel. Miroirs d'encre: rhétorique de l'autoportrait. Paris: Seuil, 1980.

COLONNA, Vincent. Tipologia da autoficção. In: NORONHA, Jovita Maria Gerheim (Org.). Ensaios sobre a autoficção. Tradução de Jovita Maria Gerheim Noronha e Maria Inês Coimbra Guedes. Belo Horizonte: UFMG, 2014. p. 39-66.

DION, Robert; FORTIER, Frances. Le portrait écrit et ses fonctions biographiques. In: DION, Robert; LEPAGE, Mahigan (Org.). Portraits biographiques. Rennes: Presses Universitaires de Rennes, 2009. p. 11-27.

ENCICLOPÉDIA Itaú Cultural de Artes Visuais, verbete auto-retrato. Disponível em <http://www.itaucultural.org.br/aplicexternas/enciclopedia_ic/Enc_Termos/ termos_imp.cfm?cd_verbete $=897 \& \mathrm{imp}=\mathrm{N} \& \mathrm{~cd} \_\mathrm{idioma}=28555>$. Acesso em: 5 jan. 2014.

ERTLER, Klaus-Dieter. Les écritures migrantes ou néo-québécoises dans le système littéraire contemporain du Québec: Sergio Kokis et "L'amour du lointain". In: MOREL, Pierre (Org.). Parcours québécois: introduction à la littérature du Québec. Chisinau: Cartier, 2007. p. 72-80.

FIGUEIREDO, Eurídice. Mulheres ao espelho: autobiografia, ficção, autoficção. Rio de Janeiro: EdUERJ, 2013.

HUSTON, Nancy. A espécie fabuladora: um breve estudo sobre a humanidade. Tradução de Ilana Heineberg. Porto Alegre: L\&PM, 2010. 
KOHLER, Héliane. Mémoire, écriture et peinture chez Sergio Kokis. L'amour du lointain - un discours d'exploration identitaire et de réflexions épistémologiques. e-CRIT3224, n. 2. Besançon: Université de Franche-Comté, 2011. Disponível em $<$ http://e-crit3224.univ- fcomte.fr/download/3224-ecrit/document/numero_2/5_ kohler_59-70.pdf $>$. Acesso em: 9 out. 2013.p. 59-70.

KOKIS, Sergio. L'amour du lointain: récit en marge des textes. Montréal: Lévesque, 2012.

A casa dos espelhos. Tradução de Marcos de Castro. Rio de Janeiro: Record, 2000.

. Errances. Montréal: XYZ, 1996a.

. Les langages de la création. Montréal: Nuit Blanche, 1996b.

LÜSEBRINK, Hans-Jürgen. Généalogie intermédiatique de l'autoportrait. In: DION, Robert; FORTIER, Frances et al (Org.). Vies en récit: formes littéraires et médiatiques de la biographie et de l'autobiographie. Montréal: Nota Bene, 2007. p. 471-96.

OUELLETTE-MICHALSKA, Madeleine. Autofiction et dévoilement de soi. Montréal: XYZ, 2007.

Recebido em: 31/08/2017

Aceito em: 15/12/2017 